\title{
The Role of Catheter Directed Thrombolysis on Acute Limb Ischemia
} (an Evidence-Based Case Report)

\author{
R. Suhartono, ${ }^{1}$ Ali Farhan Fathoni, ${ }^{2}$ \\ ${ }^{1}$ Department of surgery, division of vascular surgery, dr. Cipto Mangunkusumo General Hospital, Jakarta. \\ ${ }^{2}$ Department of surgery, Faculty of Medicine, Universitas Indonesia
}

\begin{abstract}
Introduction. Acute limb ischemia can be managed both with surgery and thrombolysis, especially catheterdirected thrombolysis. The risk, benefit and indication of thrombolysis is already well known. However, as a first line therapy, it is unclear which intervention is more beneficial; the catheter directed thrombolysis or surgery. This report aims to elucidate which technique is more effective and safer.

Method. This is an Evidence-Based Case Report based on a case of a geriatric, diabetic patient whom suffered acute limb ischemia. The report systematically search for meta-analysis, systematic review, randomized controlled trial and cohort studies from Cochrane central and PubMed for all adult patient suffering from acute limb ischemia whose are treated with catheter-directed thrombolysis or surgery as first-line intervention and comparing the outcome in terms of efficacy (clinical outcome such as patency and amputation-free rates) and safety (mortality and morbidity).

Results. Subjects' characteristics should be placed first to draw the demography. Put the study finding(s) here with no interpretation. For all adult patient regardless of their diabetic status and age there is no statistically significant difference for limb salvage, amputation, and mortality between two technique, however catheter directed thrombolysis showed reduced need for additional intervention whilst increasing risk of bleeding events.

Conclusion. Neither techniques are more superior than the other but catheter-directed thrombolysis can be considered given that it reduce the need for further intervention, less invasive and even though it has risks for bleeding complication it is still lower compared to systemic thrombolysis. The selection of which technique can be up to clinician's discretion in consideration of risk and benefit for each patient.
\end{abstract}

Keywords: Catheter directed thrombolysis, thrombectomy, acute limb ischemia.

(ISSN 2723-7494 J Bedah Indonesia. 2021;49:3-25)

Correspondending author:

Ali Farhan Fathoni, MD

Department of surgery, Faculty of Medicine, Universitas Indonesia

Email : alifarhanfathoni@gmail.com 


\section{Introduction}

This is a report based on a case of 77year-old diabetic and hypertensive woman with infra-popliteal acute limb ischemia with Rutherford category $2 \mathrm{~b}$. The patient underwent thrombectomy procedure. Three days later the clinical symptoms returned and the patient must underwent another procedure, catheter directed thrombolysis (CDT). After this second procedure, the patient symptoms improved. The author then wondered the literature evidence of CDT as a better treatment for acute limb ischemia. Acute limb ischemia (ALI) is a vascular emergency case that associated with poor prognosis and have a risk of amputation, even death. ${ }^{1,2}$ The most common management currently is still surgical thrombectomy or systemic thrombolysis. Catheter directed thrombolysis (CDT) is becoming an alternative modality in managing ALI. However, the literature evidence is still scarce and controversial.

Acute limb ischemia is defined as sudden decrease in limb perfusion, potentially threatened the limb viability and required an immediate revascularisation.1,3,4 ALI remains an important cause of morbidity and even mortality with the incidence of 1-1.5 case per 10,000 population annually. ${ }^{2}$ The symptoms of ALI is a clinical spectrum depending from the size of the affected vessel and whether or not there was previous collateral vessel that has been formed beforehand. Therefore symptoms ranges from acute white leg to no symptoms at all. The well-known general symptoms could be observed as rule of 6Ps - pain, pallor, pulse deficit, paresthesia, poikilothermic, and paresis, remains a good guide to both symptoms and sign for diagnosis ALI . 2,5 After diagnosed, ALI is classified using the TASC II or Rutherford classification that divide ALI as four categories based on clinical findings, doppler auscultation. It ranges from I-III degree from viable (I), marginally threatened (IIa), immediately threatened (IIb) and irreversible (III). ${ }^{2,6-9}$

The management of ALI is really depends on the classification ranging from conservative (I) to major amputation (III). The second category (II) require immediate revascularization given its emergency nature with thrombectomy as the most common choice. However, with the advancement of technology, endovascular procedure such as catheter directed thrombolysis could also be a choice ${ }^{5,10}$ Endovascular procedures offers minimally invasive for geriatric patient and those who have multiple morbidity. Currently the techniques for percutaneous perfusion include catheter-directed thrombolysis, pharmaco-mechanical 
Case Report

thrombolysis, catheter-directed thrombus aspiration, and percutaneous mechanical thrombectomy. This technique removes the occluding thrombus and returning perfusion back to extremity. Depending on the nature, the occluded area may be managed with angioplasty, stenting or atherectomy if it precipitated by chronic thrombus.. ${ }^{5}$ Catheter directed thrombolysis (CDT) has been a choice in multiple vascular centre to manage ALI category I-IIB. Its main principle is peripheral thrombolysis therapy directed to affected area to minimize its systemic effect. $^{2,6}$ The most commonly chosen method is USG-guided retrograde micro catheterization. This review is important because it provides available evidence as to which of these techniques is more effective in treating ALI, it also will answer the question on how is the quality of the evidence of CDT for category II ALI management and its outcome.

\section{Method}

This is an evidence-based case report that identify and critically appraised all studies that relevant on this topic. This study is reporting on catheter directed thrombolysis as a therapy for category IIb acute limb ischemia. This study included Indonesian and English studies ranging from systematic review, meta-analysis, randomized controlled trial (RCT) and prospective cohort on full-text human studies treatment of acute limb ischemia with catheter directed thrombolysis compared to surgical thrombectomy. This study excluded short communication, editorial, commentary and letter.

All adults participants with acute limb ischemia were included, regardless of its age and co-morbidity such as diabetes, arrhythmia, hypertension. This study excludes pediatric and obstetric patients, patients who have chronic limb threatening ischemia, patients that have acute limb ischemia on upper extremity, and patient with chronic vascular disease.

This study will observe the outcome from level of evidence, limb salvage, patency or recurrence, length of hospital stays, survival/mortality, amputation-free survival, distal embolization, bleeding events and excludes outcome such as technical success and economical efficacy.

This study is conducted using electronic search encompassing two major database that is Cochrane and PubMed, with some additional hand-searching of the articles. 


\section{Results}

Electronic search yields 634 articles that undergoes title and abstract screening and eligibility criteria matching. This report includes 4 systematic reviews, 1 randomized controlled trial and 1 prospective cohort as shown in this schematic on the next page. 


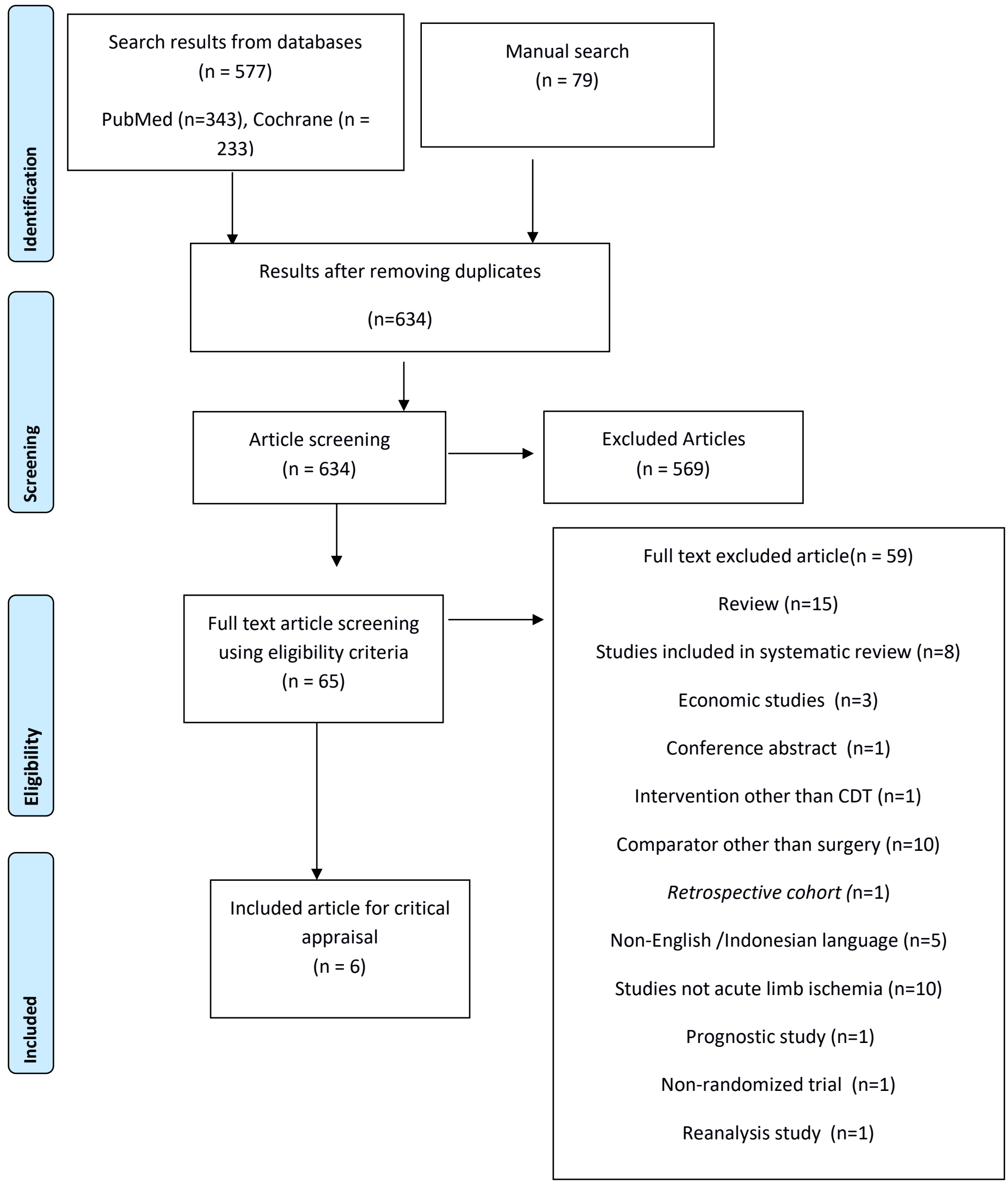


Here are the summary of the full text article :

\begin{tabular}{|c|c|c|c|c|c|c|c|}
\hline Study & Type of study & Population & Intervention & Comparator & Outcome & Writer's conclusion & $\begin{array}{c}\text { Level of } \\
\text { Evidence }^{a}\end{array}$ \\
\hline $\begin{array}{l}\text { Darwood et } \\
\text { al, 2018. }\end{array}$ & $\begin{array}{l}\text { Systematic } \\
\text { review }\end{array}$ & $\begin{array}{l}1292 \text { Patient with } \\
\text { ALI }\end{array}$ & $\begin{array}{l}\text { Non-surgical } \\
\text { Thrombolysis }\end{array}$ & Surgery & $\begin{array}{l}\text { Limb salvage, } \\
\text { amputation and } \\
\text { mortality rate on } 1 \\
\text { month, } 6 \text { months } \\
\text { and } 1 \text { year. } \\
\text { Vessel patency, } \\
\text { bleeding events, } \\
\text { stroke, distal } \\
\text { embolization, 30- } \\
\text { day need for } \\
\text { additional } \\
\text { procedure }\end{array}$ & $\begin{array}{l}\text { Neither therapy is more } \\
\text { superior in terms of limb } \\
\text { salvage on } 1 \text { month, } 6 \\
\text { months and } 1 \text { year. } \\
\text { Low quality evidence } \\
\text { showed that } \\
\text { thrombolysis have a } \\
\text { higher risk of bleeding } \\
\text { complication } \\
\text { Not statistically } \\
\text { significant difference on } \\
\text { incidence of stroke for } \\
\text { both intervention }\end{array}$ & I \\
\hline
\end{tabular}




\begin{tabular}{|c|c|c|c|c|c|c|c|}
\hline $\begin{array}{l}\text { Grip et al, } \\
2018 .{ }^{12}\end{array}$ & $\begin{array}{l}\text { Prospective } \\
\text { cohort }\end{array}$ & $\begin{array}{l}6730 \text { patients } \\
\text { with ALI } \\
\text { (3365 underwent } \\
\text { surgery }+3365 \\
\text { underwent } \\
\text { endovascular } \\
\text { procedures })\end{array}$ & $\begin{array}{l}\text { Endovascular } \\
\text { intervention }\end{array}$ & Surgery & $\begin{array}{l}\text { Vessel patency, } \\
\text { amputation rate, } \\
\text { and mortality rate } \\
\text { in } 30 \text { days. } \\
\text { Amputation-free } \\
\text { rate on } 1 \text { year and } \\
\text { 5-year survival } \\
\text { rate }\end{array}$ & $\begin{array}{l}\text { Primary endovascular } \\
\text { intervention reduce } \\
\text { mortality in comparison } \\
\text { with surgery. } \\
\text { No significant difference } \\
\text { in amputation risk. }\end{array}$ & II \\
\hline $\begin{array}{l}\text { Comerota et } \\
\text { al, } 1996 .{ }^{13}\end{array}$ & $\begin{array}{l}\text { Multi center, } \\
\text { Randomized } \\
\text { control trial, }\end{array}$ & $\begin{array}{l}174 \text { patients with } \\
\text { lower extremity } \\
\text { occlusion } \\
\\
\text { (46 underwent } \\
\text { surgery }+78 \\
\text { underwent } \\
\text { Intraarterial } \\
\text { Catheter Directed } \\
\text { Thrombolysis })\end{array}$ & $\begin{array}{l}\text { Intra-arterial } \\
\text { Catheter Directed } \\
\text { Thrombolysis with } \\
\text { recombinant } \\
\text { tissue } \\
\text { plasminogen } \\
\text { activator (rt-PA) }\end{array}$ & Surgery & $\begin{array}{l}\text { Composite } \\
\text { Clinical Outcome } \\
\text { in } 30 \text { days, } \\
\text { amputation rate } \\
\text { and morbidity }\end{array}$ & $\begin{array}{l}\text { Patients with ALI that } \\
\text { undergone surgery has a } \\
\text { better outcome with } \\
\text { bypass as its best } \\
\text { technique. But, } \\
\text { thrombolysis has a better } \\
\text { limb salvage rate. }\end{array}$ & I \\
\hline
\end{tabular}




\begin{tabular}{|c|c|c|c|c|c|c|c|}
\hline $\begin{array}{l}\text { Veenstra et } \\
\text { al, 2019. }{ }^{14}\end{array}$ & $\begin{array}{l}\text { Systematic } \\
\text { Review and } \\
\text { Meta-analysis } \\
\text { from } 25 \mathrm{RCT} \\
\text { and non-RCT }\end{array}$ & 4689 patients & Thrombolysis & Thrombectomy & $\begin{array}{l}\text { 30-day limb } \\
\text { salvage, Major } \\
\text { Vascular Outcome }\end{array}$ & $\begin{array}{l}\text { Both intervention have } \\
\text { similar limb salvage rate. } \\
\text { CDT has a higher } \\
\text { bleeding risk although } \\
\text { still lower than systemic } \\
\text { thrombolysis. }\end{array}$ & I \\
\hline $\begin{array}{l}\text { Palfreyman } \\
\text { et al, } \\
2000 .\end{array}$ & $\begin{array}{l}\text { Systematic } \\
\text { review from } 34 \\
\text { articles } \\
\text { consisting of } 10 \\
\text { RCTs and non- } \\
\text { RCTs }\end{array}$ & $\begin{array}{l}\text { Patient with } \\
\text { lower limb } \\
\text { ischemia }\end{array}$ & $\begin{array}{l}\text { Intra-arterial } \\
\text { thrombolysis }\end{array}$ & Surgery & $\begin{array}{l}\text { Mortality, } \\
\text { amputation, } \\
\text { ischemia, and life- } \\
\text { threatening } \\
\text { bleeding rate. }\end{array}$ & $\begin{array}{l}\text { Thrombolysis is more } \\
\text { superior than surgery in } \\
\text { graft occlusion and short } \\
\text { duration ischemia cases. }\end{array}$ & I \\
\hline $\begin{array}{l}\text { Wang et al, } \\
2015 .^{5}\end{array}$ & $\begin{array}{l}\text { Systematic } \\
\text { review from } 26 \\
\text { articles. }\end{array}$ & ALI patients & $\begin{array}{l}\text { Endovascular } \\
\text { intervention }\end{array}$ & Surgery & $\begin{array}{l}\text { Short-term vessel } \\
\text { patency, limb } \\
\text { salvage, } \\
\text { amputation free } \\
\text { rate, mortality and } \\
\text { complication. }\end{array}$ & $\begin{array}{l}\text { Endovascular } \\
\text { intervention is safer and } \\
\text { more effective to salvage } \\
\text { limb than surgery. } \\
\text { Endovascular } \\
\text { intervention and surgery } \\
\text { could complement each } \\
\text { other. }\end{array}$ & I \\
\hline
\end{tabular}


Following is the assessment of critical appraisal for each studies.

\begin{tabular}{|c|c|c|c|c|}
\hline $\begin{array}{l}\text { CEBM QFAITH APPRAISAL } \\
\text { TOOL. }{ }^{16}\end{array}$ & Darwood et al, 2018 & Veenstra et al, 2019 & Palfreyman et al, 2000 & Wang et al, 2015 \\
\hline \multicolumn{5}{|l|}{ VALIDITY - is this review valid? } \\
\hline $\begin{array}{l}\text { Did the systematic review } \\
\text { ask a focused question? } \\
\text { (PICO) }\end{array}$ & Yes & Yes & Yes & Yes \\
\hline $\begin{array}{l}\text {...and used it to find and } \\
\text { choose included article? }\end{array}$ & Yes & Yes & No & UNCLEAR \\
\hline $\begin{array}{l}\mathrm{F} \text { - did the search find all of } \\
\text { relevant evidence? }\end{array}$ & Yes & No & No & No \\
\hline $\begin{array}{l}\text { A -Have all studies } \\
\text { undergone critical appraisal? }\end{array}$ & Yes & Yes & Yes & No \\
\hline $\begin{array}{l}\text { I-Did this review only } \\
\text { include high quality study? }\end{array}$ & No & No & No & No \\
\hline $\begin{array}{l}\text { T-Is there result totaled up } \\
\text { using appropriate summary } \\
\text { and plot? }\end{array}$ & Yes & Yes & No & No \\
\hline
\end{tabular}




\begin{tabular}{|c|c|c|c|c|}
\hline $\begin{array}{l}\mathrm{H} \text { - Did the study assess and } \\
\text { explained heterogeneity } \\
\text { between studies? }\end{array}$ & Yes & No & Yes & No \\
\hline \multicolumn{5}{|c|}{ IMPORTANCE - How are the results? } \\
\hline $\begin{array}{l}\text { What measure was used, } \\
\text { how large the effect, could it } \\
\text { have been due to chance? }\end{array}$ & $\begin{array}{l}\text { Limb salvage (OR) } \\
30 \text { days: } 1.02(0.41-2.55), P=0.97, \\
I^{2}=56 \% \\
6 \text { months: } 0.86(0.59-1.26) \\
1 \text { year: } 0.88(0.62-1.23) p=0.44, I^{2}= \\
48 \% \\
\text { Amputation (OR) } \\
30 \text { days: } 0.97(0.51-1.85) p=0.93 \\
I^{2}=43.19 \% \\
6 \text { months: } 1.16(0.79-1.7) \\
1 \text { year: } 1.13(0.82-1.55) P=0.47 I^{2}= \\
0 \% \\
\text { Mortality }(O R) \\
30 \text { days: } 0.59(0.3-1.14), p=0.12 \\
I^{2}=0 \% \\
6 \text { months: } 1.35(0.83-2.19) \\
1 \text { year: } 0.67(0.25-1.79), p=\left.0.42\right|^{2}=\end{array}$ & 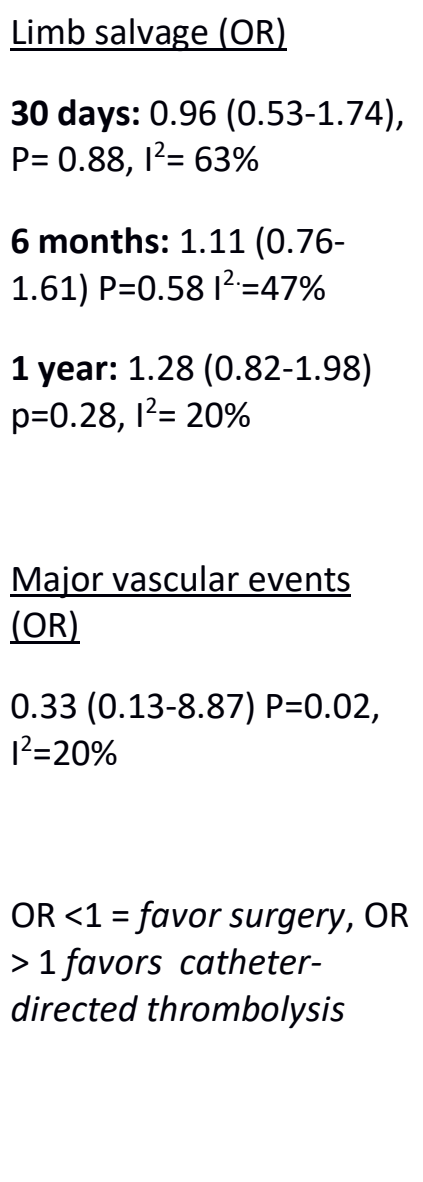 & 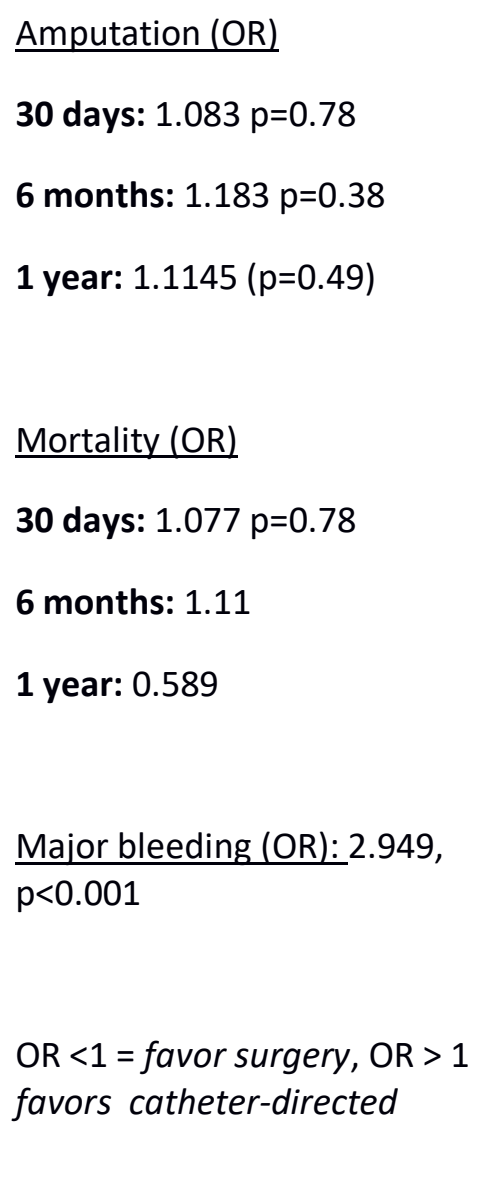 & $\begin{array}{l}\text { 30-day mortality post- } \\
\text { operation (\%) } \\
\text { Surgery vs } \\
\text { Endovascular } \\
\text { intervention } \\
12.1 \% \text { vs } 6.7 \%\end{array}$ \\
\hline
\end{tabular}




\begin{tabular}{|c|c|c|c|c|}
\hline & $\begin{array}{l}79.03 \% \\
\text { Other complication (30 days, OR) } \\
\text { Vessel patency: } 0.46(0.08-2.76) \\
\text { Major bleeding: } 3.22(1.79-5.78), \\
P<0.001, I^{2}=0 \% \\
\text { Stroke: } 5.33(0.95-30.11) p=0.06, \\
I^{2}=0 \% \\
\text { Distal embolization: } 31.68 \text { (6.23- } \\
161.07) \text { p }<0.001, I^{2}=33.29 \% \\
\text { Reducing additional intervention } \\
:^{*} 9.06 \text { (4.55-16.56) } p<0.001, \\
I^{2}=17.07 \\
*=\text { favors thrombolysis } \\
\text { Others: } \\
\text { OR }>1 \text { = favor surgery, OR }<1 \\
\text { favors thrombolysis }\end{array}$ & & thrombolysis & \\
\hline $\begin{array}{l}\text { How are the results totaled } \\
\text { up? }\end{array}$ & Forest plot & Forest plot & Forest plot & Table \\
\hline
\end{tabular}




\begin{tabular}{|c|c|c|c|c|}
\hline \multicolumn{5}{|c|}{ APPLICABILITY - Can we apply the results to our patient? } \\
\hline $\begin{array}{l}\text { Is the population so different } \\
\text { with the study so the result } \\
\text { can't help our patient? }\end{array}$ & No & No & No & No \\
\hline $\begin{array}{l}\text { Is the intervention possible } \\
\text { to be done in the writer's } \\
\text { setting? }\end{array}$ & Yes & Yes & Yes & Yes \\
\hline $\begin{array}{l}\text { Is the benefit outweight the } \\
\text { risk for the patient. }\end{array}$ & $\begin{array}{l}\text { Yes, as long as the patient is } \\
\text { assessed carefully and agreeing to } \\
\text { possible risk. }\end{array}$ & Yes & Yes & \\
\hline \multicolumn{5}{|l|}{ Relevance } \\
\hline Similar population & Yes & Yes & Yes & Yes \\
\hline Similar intervention & Yes & Yes & Yes & Yes \\
\hline Similar outcome & Yes & Yes & Yes & Yes \\
\hline
\end{tabular}


Here are the appraisal result for cohort studies

\begin{tabular}{|l|l|}
\hline \multicolumn{2}{|l|}{ CEBM TOOLS. ${ }^{17}$} \\
\hline VALIDITY \\
\hline $\begin{array}{l}\text { Is the patient representative that defined at a same point } \\
\text { (usually at the beginning) of their condition? }\end{array}$ & Yes \\
\hline \begin{tabular}{l} 
Is the follow-up period adequate and complete? \\
\hline $\begin{array}{l}\text { Is the outcome criteria objective or conducted in blind } \\
\text { fashion? }\end{array}$
\end{tabular} & Yes \\
\hline $\begin{array}{l}\text { Did different subgroup with different prognosis identified } \\
\text { and adjusted with important prognostic factor? }\end{array}$ & Yes \\
\hline $\begin{array}{l}\text { Is there a validation on an independent group? (test-set)? } \\
\text { IMPORTANCE }\end{array}$ & No \\
\hline $\begin{array}{l}\text { How large the outcome possibility within the time } \\
\text { period? }\end{array}$ & \\
\hline
\end{tabular}




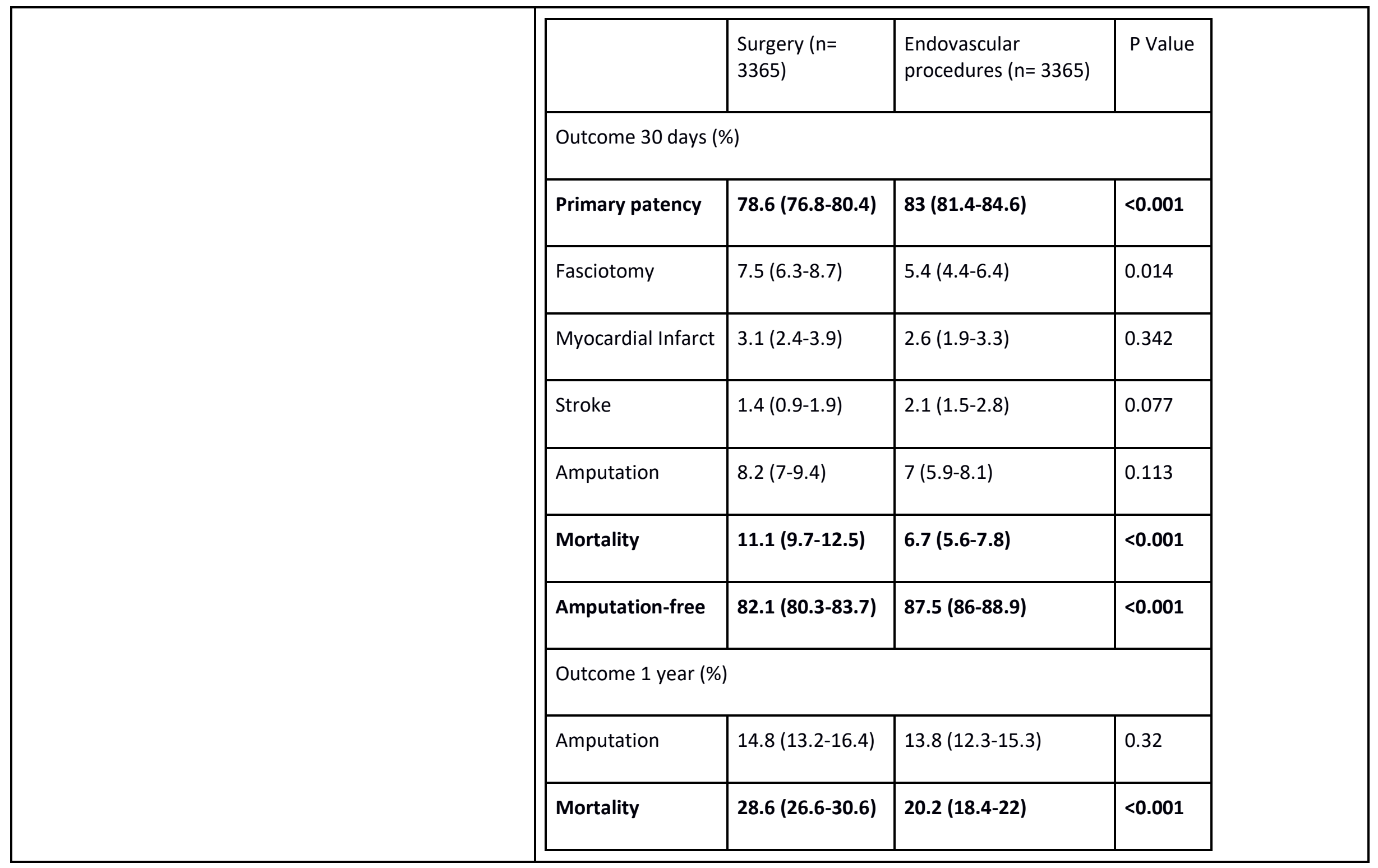




\begin{tabular}{|c|c|c|c|c|}
\hline & Amputation-free & $61.6(59.4-63.7)$ & $69.9(67.9-71.9)$ & $<0.001$ \\
\hline How precise is the prognostic estimate? & \multicolumn{4}{|c|}{ Using a quite narrow confidence interval (CI) 95\% } \\
\hline \multicolumn{5}{|l|}{ APPLICABILITY } \\
\hline Is the patient from the studies similar to our patient? & \multicolumn{4}{|l|}{ Yes } \\
\hline $\begin{array}{l}\text { Is the evidence from the report produce clinically } \\
\text { important information that can be offered to our patient? }\end{array}$ & \multicolumn{4}{|c|}{$\begin{array}{l}\text { Yes, generally endovascular intervention is more superior for preventing mortality and } \\
\text { generally have a better amputation-free rate although extra caution need to be taken in } \\
\text { order to avoid bleeding risks. }\end{array}$} \\
\hline
\end{tabular}


Lastly here is the appraisal for the RCT

\begin{tabular}{|c|c|}
\hline CEBM TOOLS. ${ }^{18}$ & Comerota et al, 1996 \\
\hline \multicolumn{2}{|l|}{ Validity } \\
\hline Is the intervention randomized? & Yes \\
\hline And the randomized list (concealed)? & No \\
\hline $\begin{array}{l}\text { Did all patients participating in the trial well documented at the end of } \\
\text { the trial? Are they analyzed according to their randomized group? }\end{array}$ & Yes \\
\hline Did all patients blinded from the intervention? & No \\
\hline Other than the intervention, did all groups treated equally? & Yes \\
\hline Did the patients have similar characteristics at the beginning of the trial? & Yes \\
\hline \multicolumn{2}{|l|}{ Importance } \\
\hline What are the results from the trial? & $\begin{array}{l}\text { Composite clinical outcome * } \%) \text { : } \\
\text { Surgery vs catheter directed thrombolysis: } 30 \text { days: } 39 \% \text { vs } 60 \%(P=0.02) \\
1 \text { Year: } 61 \% \text { vs } 78 \%(P=0.04)\end{array}$ \\
\hline
\end{tabular}




\begin{tabular}{|l|l|}
\hline & $\begin{array}{l}\text { Clinical Improvement (\%): } \\
\text { Surgery vs catheter directed thrombolysis: } \\
30 \text { days: } 62 \% \text { vs } 80 \%\end{array}$ \\
\hline Applicability & $\begin{array}{l}\text { *= if at least one of the following occurred: post-operative infection, major } \\
\text { bleeding, ischemic recurrence, revascularization failure, death, amputation, } \\
\text { perioperative complication. }\end{array}$ \\
\hline $\begin{array}{l}\text { Did our patient so different than those in the trial that the results can't be } \\
\text { used to help the patients? }\end{array}$ & No \\
\hline Did the intervention possible in the writer's setting? & Yes \\
\hline Is the benefit potentially outweigh the risk towards the patient? & Yes \\
\hline
\end{tabular}


After conduction critical appraisal on all included studies it can be concluded that all included studies is valid, although the quality and level of evidence may vary (I-II). All the systematic review include a clear eligibility criteria and for cohort and RCT studies use a similar sample. It is worth noting that only Darwood et al, ${ }^{11}$ studies include publication bias assessment and has proof of finding unpublished material. All the systematic review use OR as measurement in which the result will be more exaggerated than using Relative Risk (RR). ${ }^{19}$ All studies has properly totaled up their result except for Wang et $\mathrm{al}^{5}$. Not all article included in systematic review is high quality article where there are certain risk of bias especially blinding, however it is impossible to double blind this study given that this is a surgical/interventional treatment.

The study included use various measure but this report find some common thread. First, generally there is no statistically significant difference for both techniques in term of limb salvage, amputation and mortality, except on prospective cohort by Grip et al where it leans toward CDT. Second, most of the studies have a wide range of confidence interval except from the cohort study, additionally in systematic reviews articles there are abundance of heterogeneity.

After looking at all of the studies, the main advantage of CDT usage is reducing additional surgery, primary vessel patency and clinical improvement whilst increasing the risk of major vascular event. Furthermore, CDT procedure also increasing risk of distal embolization and adverse clinical event that were included in composite outcome as demonstrated in RCT by Comerota et al ${ }^{13}$

Patient from the case have similar characteristics with the included studies because all studies include all ALI patients despite its comorbidities such as diabetes and no age limit, as long as the participants are adult. Both of the technique has been done in Indonesia so it is possible to adopt and compare the results.

\section{Discussion}

This report was based on a case to compare the outcome of catheter directed thrombolysis (CDT) with conventional thrombectomy. After a systematic search, the report critically analyzed 6 different studies ranging from systematic review, multi-center randomized controlled trial and prospective cohort.

This report finds a common thread that there were no statistically significant 
differences between CDT and surgery in terms of mortality, amputation and limb salvage rate that evaluated for 30 days, 6 months and 1 year. However, it is worth noting that there was a data in cohort study stating that CDT reduce the mortality and amputation rate. Additionally catheter directed thrombolysis is better in preventing additional intervention to maintain vessel's patency, leading to better clinical improvement. On the other hand, CDT increased the additional risk of bleeding events compared to surgery, however it is still lower than systemic thrombolysis.

It is quite difficult to take a clear conclusion which of the technique is more superior. This is attributed to variance in data per study, the difference in result measurement unit (the systematic review uses odds ratio whereas the primary study use percentage from the population). All of the study also varies in quality.

The study from Darwood et al ${ }^{11}$, the most comprehensive systematic review in terms of search and methods, concluded that there was no significant difference between two technique. Even though this study include data from primary studies that have risk of performance and detection bias it still rather tolerable given that the outcome such as mortality and amputation is objective enough that it will not need to be blinded and it is also impossible to have a double-blind trial since the clinician will realize what they are intervening. The study from Veenstra et $\mathrm{al}^{14}$ is the most recent study from this report. This study have the most updated information but did not explain its heterogeneity and did not have an evidence of non-published material searching. The study from Palfreyman et al, ${ }^{15}$ which was conducted in 2000, have a better scope of primary studies. However, it also did not explain its heterogeneity, showed no evidence of grey literature searching and quite lacking in their eligibility criteria.

These systematic reviews also shows no significant difference between CDT and surgery in amputation, mortality and limb salvage rates, it also agreed with Darwood et al that CDT increase the risk of bleeding events. All of this systematic review has a significant level of heterogeneity but this is could be explained because of these reviews include all adult acute limb ischemia regardless their stadium, anatomic location of the ischemia, their diabetic status and for the CDT intervention, all thrombolytic agents. The benefits of preventing further intervention could be put into consideration by the clinician given that these four studies give the discretion to the clinician to pick the technique and weighing the risk and benefits of the selected procedure. 
For the results of the primary study, a prospective cohort study by Grip et al, ${ }^{12}$ measured the outcome in 30 days and 1-year period and showed the main benefits of CDT is reducing the mortality and amputation risk. Although it is a comprehensive prospective cohort its level of evidence is lower than systematic review and they compare the data using percentage of the population. On the other hand, a multi-center RCT by Comerota et $\mathrm{al}^{13}$ conclude that CDT usage yields a better clinical improvement even though it increased the risk of composite clinical outcome incidence.

Based on this critical analysis, this report conclude that all included studies are valid despite its heterogeneity and variability. This heterogeneity and variability between the studies also making it impossible to conclude which of the technique is absolutely more superior.

This report showed an empirical benefit from CDT as long as bleeding risk can be minimized and post-operation followup can be done rigorously.

\section{Conclusion}

The use of catheter directed thrombolysis is in accordance with current evidence and supported by all the studies. This technique is better in terms of primary vessel patency, clinical outcome and reducing the needs for additional intervention, however catheter directed thrombolysis has an increased risk of bleeding events compared to surgery even though the risk is still lower than systemic thrombolysis. There's no statistically significant difference in mortality and amputation rate between the two techniques but it is worth mentioning that catheter directed thrombolysis is a less invasive technique. At the end neither technique is more superior than the other so the selection can be up to the clinician's discretion weighing its risk and benefit.

\section{Disclosure}

Statement of no conflict of interest.

\section{Acknowledgement}

For those acknowledged. 


\section{References}

1. Morrison, HL. Catheter-directed Thrombolysis for Acute Limb Ischemia. Semin Intervent Radiol. 2006; 23(3): 258-269

2. Obara H, Matsubara K, Kitagawa Y. Acute Limb Ischemia. Ann Vasc Dis. Japan. 2018; 11(4): 443-448

3. Wang JC, Kim AH, Kashyap VS. Open Surgical or Endovascular Revascularization for Acute Limb Ischemia. J Vasc Surg. Society for Vascular Surgery. 2016; 63(1): 270-278

4. Theodoridis PG, Davos CH, Dodos I, Iatrou N, Potouridis A, Pappas GM, et al. Thrombolysis in Acute Lower Limb Ischemia: Review of the Current Literature. Ann Vasc Surg. Elsevier Inc. 2018; 52: 255262

5. Jack L, Cronenwett KWJ. Rutherford's Vascular Surgery. 8 ed. Vol. 2. Philadelphia: Elsevier. 2014

6. McNally MM, Univers J. Acute Limb Ischemia. Surg Clin North Am. Elsevier Inc. 2018; 98(5): 1081-1096

7. $\mathrm{Hj}$ DVOS, Aortic SJ. Clinical Classification of Acute Limb Ischaemia. Eur J Vasc Endovasc Surg. 2010; 19: 122-124

8. Norgren L, Hiatt WR, Dormandy JA, Nehler MR, Harris KA, Fowkes $\mathrm{FG}$, et al. Inter-society Consensus for The Management of Peripheral Arterial Disease. Int Angiol. 2007; 26(2): 157-181

9. Rutherford RB. Clinical Staging of Acute Limb Ischemia as The Basis for Choice of Revascularization Method: When and How to
Intervene. Semin Vasc Surg. Elsevier Inc.; 2009; 22(1): 5-9

10. Ouriel K. Endovascular Techniques in The Treatment of Acute Limb Ischemia: Thrombolytic Agents, Trials, and Percutaneous Mechanical Thrombectomy Techniques. Semin Vasc Surg. 2003; 16(4): 270-9

11. Darwood R, Berridge D, Kessel D, Robertson I, Forster R. Surgery versus thrombolysis for initial management of acute limb ischaemia. Cochrane Database of Systematic Reviews [Internet]. 2018;(8). Available from: http://dx.doi.org/10.1002/14651858 .CD002784.pub3

12. Grip O, Wanhainen A, Michaelsson $\mathrm{K}$, Lindhagen L, Bjorck M. Open Versus Endovascular Revascularization for the Treatment of Acute Lower Limb Ischaemia: a Nationwide Cohort Study. European journal of vascular and endovascular surgery. 2019;58(6):e119-e120.

13. Comerota A, Weaver F, Hosking J, Froehlich J, Folander H, Sussman $\mathrm{B}$, et al. Results of a prospective, randomized trial of surgery versus thrombolysis for occluded lower extremity bypass grafts. American journal of surgery. 1996;172(2):105-112.

14. Veenstra EB, van der Laan MJ, Zeebregts CJ, de Heide E-J, Kater M, Bokkers RPH. A systematic review and meta-analysis of endovascular and surgical revascularization techniques in acute limb ischemia. J Vasc Surg. 2020 Feb;71(2):654-668.e3. 
15. Palfreyman SJ, Booth A, Michaels JA. A systematic review of intraarterial thrombolytic therapy for lower-limb ischaemia. Eur J Vasc Endovase $\quad$ Surg. 2000 Feb;19(2):143-57.

16. Centre for Evidence-Based Medicine. Systematic reviews critical appraisal sheet [Internet]. University of Oxford; 2021. Available from: https://www.cebm.ox.ac.uk/resourc es/ebm-tools/critical-appraisaltools

17. Elwood M. Critical appraisal of a prospective cohort study [Internet]. Vol. 1. Oxford University Press; 2017 [cited 2021 Jun 8]. Available from:

http://www.oxfordmedicine.com/vi ew/10.1093/med/9780199682898.0 01.0001/med-9780199682898chapter-14

18. Centre for Evidence-Based Medicine. Therapy study [Internet]. University of Oxford; 2021. Available from: https://www.cebm.ox.ac.uk/resourc es/ebm-tools/critical-appraisal-tool

19. Ranganathan P, Aggarwal R, Pramesh C. Common pitfalls in statistical analysis: Odds versus risk. Perspect Clin Res. 2015;6(4):222. 